OPEN ACCESS

Edited by:

Vincent David,

Centre National de la Recherche

Scientifique, France

Reviewed by:

Aviv M. Weinstein, University of Ariel, Israel Hedy Kober,

Yale University, USA

*Correspondence:

Jean Lud Cadet jcadet@intra.nida.nih.gov;

Veronica Bisagno

vbisagno@ffyb.uba.ar

Specialty section:

This article was submitted to

Addictive Disorders,

a section of the journal

Frontiers in Psychiatry

Received: 19 April 2015 Accepted: 27 December 2015

Published: 15 January 2016

Citation:

Cadet JL and Bisagno V (2016) Neuropsychological Consequences of Chronic Drug Use: Relevance to

Treatment Approaches.

Front. Psychiatry 6:189.

doi: 10.3389/fpsyt.2015.00189

\section{Neuropsychological Consequences of Chronic Drug Use: Relevance to Treatment Approaches}

\author{
Jean Lud Cadet ${ }^{1 *}$ and Veronica Bisagno ${ }^{2 *}$ \\ ${ }^{1}$ National Institute on Drug Abuse Intramural Program, Molecular Neuropsychiatry Research Branch, Baltimore, MD, USA, \\ ${ }^{2}$ Instituto de Investigaciones Farmacológicas (ININFA), Universidad de Buenos Aires-CONICET, Buenos Aires, Argentina
}

Heavy use of drugs impacts of the daily activities of individuals in these activities. Several groups of investigators have indeed documented changes in cognitive performance by individuals who have a long history of chronic drug use. In the case of marijuana, a wealth of information suggests that heavy long-term use of the drug may have neurobehavioral consequences in some individuals. In humans, heavy cocaine use is accompanied by neuropathological changes that might serve as substrates for cognitive dysfunctions. Similarly, methamphetamine users suffer from cognitive abnormalities that may be consequent to alterations in structures and functions. Here, we detail the evidence for these neuropsychological consequences. The review suggests that improving the care of our patients will necessarily depend on the better characterization of drug-induced cognitive phenotypes because they might inform the development of better pharmacological and behavioral interventions, with the goal of improving cognitive functions in these subsets of drug users.

Keywords: marijuana, cocaine, methamphetamine, frontal cortex, cognition

\section{INTRODUCTION}

Substance use disorders continue to be a major health concern worldwide. Chronic use of various drugs can impact brain structures and functions $(1,2)$. Use of these drugs may also be associated with both acute and chronic neuropsychological abnormalities (3). The present review summarizes some of the evidence documenting cognitive changes reported in drug users [with a focus on marijuana, cocaine, and methamphetamine (METH)]. We also discuss potential biological substrates for these observations. The neuropathological changes associated with the use of larger quantities of some of these drugs have been recently reviewed (1). In addition to having differential abuse liability, the use of some of these substances is also associated with differential pathoanatomic changes in the brain (1). There is also evidence that a history of substance use may also exacerbate pre-existing neuropsychological deficits (4) and comorbid neurological or psychiatric disorders (3). It is also clear that substance-related changes in neuropsychological functions may negatively impact activities of daily living, including ability to manage finances and/or holding on to jobs (5). A meta-analysis of METH users and cognition revealed that these individuals exhibited small-to-medium effect sizes for an association between neurocognitive impairment and employment (6). Cognitive domains associated with employment status included executive function, learning and memory, attention, and general intellectual ability (6). In the present review, we will discuss alterations that are linked to psychological and neural mechanisms that detect error signals and generate suitable behavioral 
responses (7). Also discussed is the accumulated evidence of poor learning and memory, diminished executive functions, and risky decision-making in some individuals with a history of heavy drug use (8-11).

\section{MARIJUANA USE}

Marijuana is the most commonly used illicit substance (12). Investigations of cognitive functions in heavy marijuana users have recently documented poor performance in a number of cognitive subdomains. Some of these deficits appear to be related to frequency of drug use and can impact activities of daily living.

\section{Neuropsychological Findings}

Adult marijuana users suffer from changes measured in broad cognitive domains $(13,14)$. These include memory $(9,13,14,15)$, attention (16), decision-making (17), and psychomotor speed (9, 18). Bolla et al. (9) reported that impairments observed in marijuana users could be measured in heavy users even after 28 days of forced abstinence during their participant stay on a closed research unit, with light use of marijuana not being associated with any significant decrements in performance (9). In a recent study, Colizzi et al. (19) studied whether functional variations in cannabinoid receptor 1 (CNR1) gene and marijuana exposure interact to modulate prefrontal functions and related behaviors. The authors suggested that deleterious effects of marijuana use may be more evident in individuals with specific genetic backgrounds that might impact receptor expression (19). Additionally, it is important to note that, even if marijuana use during early adulthood is associated with cognitive impairments in selected domains, prolonged abstinence may promote improvement in performance $(13,14,20)$. These data are summarized in Table $\mathbf{1}$.

Functional imaging studies comparing activation in both adult and adolescent chronic marijuana users to healthy controls during the performance of different cognitive tasks have reported that chronic marijuana users showed altered patterns of brain activity [Ref. (31-38), see Table 2]. There is also evidence to suggest that heavy marijuana use may produce deficits on measures of decision-making and inhibitory control that persist for long periods of time (27). Among recreational marijuana users, lack of inhibitory control depends on contextual or situational factors, with loss of control being evident only when situations or tasks involve a motivational component (27). Also, poorer cognitive performance in areas of risk-taking, decision-making, and episodic memory may influence the degree to which marijuana users engage in risky behaviors with consequent negative health consequences (39). In addition, it has been reported that the main active ingredient in marijuana, delta- 9 tetrahydrocannabinol (THC), can alter time perception by impairing time estimation and production in the seconds range (30). Temporal processing changes may have functional consequences because it is relevant to many everyday tasks, including driving (30).

Interestingly, although much more in-depth research remains to be done on this controversial issue, marijuana use during adolescence has been reported to increase the risk of developing psychotic disorders later in life (40). THC was also reported to induce acute psychotic symptoms in healthy individuals (41)
TABLE 1 | Cognitive deficits reported in marijuana users.

\begin{tabular}{|c|c|c|}
\hline Reference & Cannabis dependence & Cognitive findings \\
\hline Solowij et al. $(21,22)$ & Adult chronic users & $\downarrow$ Attention \\
\hline Pope et al. $(13,14)$ & $\begin{array}{l}\text { Adult heavy users (abstinent) } \\
\text { Adult moderate users } \\
\text { (abstinent) }\end{array}$ & $\downarrow$ Verbal memory \\
\hline Bolla et al. (9) & Adult abstinent users & $\begin{array}{l}\downarrow \text { Verbal memory } \\
\downarrow \text { Visual memory } \\
\downarrow \text { Executive function } \\
\downarrow \text { Psychomotor speed } \\
\downarrow \text { Manual dexterity }\end{array}$ \\
\hline Lyons et al. (23) & $\begin{array}{l}\text { Adult abstinent users } \\
\text { Twin study }\end{array}$ & $\downarrow$ General intelligence \\
\hline Medina et al. (24) & Adolescent abstinent users & $\downarrow$ Executive function \\
\hline Hanson et al. (25) & Adolescent abstinent users & $\begin{array}{l}\downarrow \text { Verbal memory } \\
\downarrow \text { Attention } \\
\downarrow \text { Working memory }\end{array}$ \\
\hline Battisti et al. (26) & Adult chronic users & $\downarrow$ Memory recall \\
\hline $\begin{array}{l}\text { Griffith-Lendering } \\
\text { et al. ( } 27)\end{array}$ & Adult recreational users & $\downarrow$ Inhibitory control \\
\hline \multirow[t]{2}{*}{ Meier et al. (28) } & $\begin{array}{l}\text { Adolescent onset vs. adult } \\
\text { onset }\end{array}$ & $\downarrow \mathrm{IQ}$ \\
\hline & Prospective study & $\begin{array}{l}\downarrow \text { Working memory } \\
\downarrow \text { Reasoning }\end{array}$ \\
\hline Solowij et al. (29) & Adolescent chronic users & $\begin{array}{l}\downarrow \text { Decision-making, } \\
\text { increased impulsivity }\end{array}$ \\
\hline Sewell et al. (30) & Frequent and infrequent users & $\begin{array}{l}\downarrow \text { Temporal processing } \\
\text { in infrequent users }\end{array}$ \\
\hline
\end{tabular}

$\downarrow$, Cognitive deficits.

and to increase the risk of psychotic disorders after long-term use (42). A recent study by Bhattacharyya et al. (43) reported a significant relationship between the effects of THC on striatal activation, its effects on task performance, and appearance of positive psychotic symptoms, suggesting that THC might induce psychosis by influencing the neural substrate of attentional salience processing (43). Although more research is needed on this subject, there are plausible biochemical pathways that marijuana can impact to induced psychotic responses in some individuals. Specifically, the endocannabinoid system consists of cannabinoids receptors and endogenous cannabinoid ligands that interact with these receptors to impact the release of several neurotransmitters, including GABA, glutamate, and dopamine $(44,45)$. Therefore, it seems possible that exposure to marijuanabased psychoactive substances during adolescence could negatively impact glutamatergic and GABAergic systems, with subsequent alterations of maturation processes of these systems, resulting in psychosis-like phenomena (46). The appearance of psychiatric disturbances might also depend on the exact dose, time windows during adolescence, and/or duration of drug exposure $(24,28,40)$. Interestingly, hair analyses also revealed that marijuana users with high THC concentration were more likely to exhibit schizophrenia-like symptoms $(47,48)$. Some of the neuroimaging and cognitive changes reported in marijuana users appear to be moderated by gender $(24,49)$. These findings highlight potential THC-induced neuroadaptations in the 
TABLE 2 | Functional neuroimaging studies on marijuana users performing cognitive tasks.

\begin{tabular}{|c|c|c|c|}
\hline Reference & Cannabis dependence & Neuroimaging method & Main findings \\
\hline Block et al. (15) & Adult chronic users & PET & $\begin{array}{l}\downarrow \text { Verbal memory } \\
\downarrow \text { Activation in PFC } \\
\uparrow \text { Activation in cerebellum }\end{array}$ \\
\hline Bolla et al. (17) & Adult abstinent users & PET & $\begin{array}{l}\downarrow \text { Decision-making } \\
\downarrow \text { Activation in DLPC and OFC } \\
\uparrow \text { Activation in cerebellum }\end{array}$ \\
\hline Chang et al. (31) & $\begin{array}{l}\text { Adult chronic users } \\
\text { Adult abstinent users }\end{array}$ & $\mathrm{fMRI}$ & $\begin{array}{l}\downarrow \text { Activation in cerebellum } \\
\text { Altered activation pattern in the attention network }\end{array}$ \\
\hline Padula et al. (32) & Adolescent abstinent users & $\mathrm{fMRI}$ & $\begin{array}{l}\uparrow \text { Activation in temporal gyrus, ACC } \\
\downarrow \text { Activation in thalamus, pulvinar, left temporal gyrus }\end{array}$ \\
\hline Tapert et al. (33) & Adolescent abstinent users & $\mathrm{fMRI}$ & $\begin{array}{l}\uparrow \text { Activation in DLPC, medial frontal cortex, parietal, and } \\
\text { occipital gyrus }\end{array}$ \\
\hline Schweinsburg et al. (34) & Adolescent abstinent users & $\mathrm{fMRI}$ & $\begin{array}{l}\uparrow \text { Activation in parietal cortex } \\
\downarrow \text { Activation in DLPC and occipital cortex }\end{array}$ \\
\hline Hester et al. (35) & Adult chronic users & $\mathrm{fMRI}$ & $\begin{array}{l}\downarrow \text { Monitoring of interoceptive awareness } \\
\downarrow \text { Activation in insula, ACC, parietal, and frontal cortex }\end{array}$ \\
\hline Abdullaev et al. (16) & Young adult chronic users & $\mathrm{fMRI}$ & $\begin{array}{l}\downarrow \text { Attention } \\
\uparrow \text { Activation in PFC and parietal cortex }\end{array}$ \\
\hline King et al. (18) & Adult chronic users & $\mathrm{fMRI}$ & $\begin{array}{l}\downarrow \text { Psychomotor speed } \\
\downarrow \text { Activation in lingual gyrus } \\
\uparrow \text { Activation in frontal gyrus }\end{array}$ \\
\hline Wesley et al. (37) & Adult chronic users & $\mathrm{fMRI}$ & $\begin{array}{l}\downarrow \text { Decision-making } \\
\downarrow \text { Activation in cerebellum, ACC, parietal, and frontal } \\
\text { cortex }\end{array}$ \\
\hline Harding et al. (38) & Adult chronic users & $\mathrm{fMRI}$ & $\begin{array}{l}\uparrow \text { Functional connectivity between PFC and } \\
\text { occipitoparietal cortex }\end{array}$ \\
\hline
\end{tabular}

ACC, anterior cingulate cortex; DLPC, dorsal lateral prefrontal cortex; PFC, prefrontal cortex; $\downarrow$, decreased brain activation; $\uparrow$, increased brain activation; $\downarrow$, cognitive deficits.

adolescent brain and support the importance of prevention and treatment of adolescent users (28). Nevertheless, this topic needs to be further investigated before any firm conclusion can be reached concerning the relationship of THC to psychosis and other psychiatric diseases.

\section{COCAINE USE}

Although cocaine is a highly addictive agent, the vast majority of cocaine users do so recreationally over extended periods of time without developing dependence (50). Thus, documenting the potential cognitive effects of cocaine is an important public health issue because of its high prevalence in the general population. Recent neurobehavioral studies have shown that cocaine heavy users show a number of cognitive decrements that may be secondary to cocaine-induced changes in brain structure and function (1). These cognitive deficits are detailed below.

\section{Neuropsychological Findings}

Heavy cocaine use is associated with decrements in performance in several cognitive domains [Ref. (51), detailed in Table 3]. These include problems in executive function, decision-making, increased impulsivity, abnormal visuoperception, abnormal psychomotor speed, impaired manual dexterity, poor verbal learning, and decrements in memory functions (8, 52-58). Additionally, cocaine users showed different patterns of brain activation while performing cognitive tasks [Ref. (59-67), see Table 4]. Chronic cocaine users show poor insight and judgment, lack foresight, and are also disinhibited (68). These cognitive changes are probably related to functional dysfunctions in the prefrontal cortex (69) since patients who suffer damage in this brain region manifest similar cognitive problems (70). This suggestion is supported by neuroimaging studies demonstrating hypofrontality in cocaine users performing tasks of attention and executive function $(62,71)$. From this perspective, the possibility that a core deficit in executive functions, such as context processing, might contribute to the well-documented impairments in top-down control that are commonly associated with heavy cocaine use (72). In addition to those observations in chronic heavy cocaine users, subtle cognitive deficits have been reported in non-dependent, recreational cocaine users (50, 73-76).

There is a compelling evidence to suggest that cocaine-associated impairments in cognitive functioning might be secondary to cocaine-induced dysfunctions in dopaminergic systems (88-93). Cerebral hypoperfusion observed in the frontal and temporoparietal cortical areas of cocaine users $(77,94)$ may also subserve some of the observed cognitive deficits in these patients. These suggestions are consistent with the report of increased cerebral vascular resistance in cocaine users, abnormalities that lasted for, at least, 1 month of monitored abstinence (95).

In addition to specific deficits observed in cocaine users, these individuals may also suffer from psychosocial impairments. For 
TABLE 3 | Cognitive deficits reported in cocaine users.

\begin{tabular}{|c|c|c|}
\hline Reference & Cocaine dependence & Cognitive findings \\
\hline Ardila et al. (52) & Adult chronic users & $\begin{array}{l}\downarrow \text { Verbal memory } \\
\downarrow \text { Attention }\end{array}$ \\
\hline O’Malley et al. (53) & Adult chronic users & $\begin{array}{l}\downarrow \text { Verbal memory } \\
\downarrow \text { Intelligence } \\
\downarrow \text { Verbal abilities } \\
\downarrow \text { Global } \\
\text { neuropsychological } \\
\text { functioning }\end{array}$ \\
\hline Strickland et al. (77) & Adult abstinent users & $\begin{array}{l}\downarrow \text { Attention } \\
\downarrow \text { Visual memory } \\
\downarrow \text { Psychomotor speed }\end{array}$ \\
\hline Hoff et al. (54) & Adult abstinent users & $\begin{array}{l}\downarrow \text { Spatial memory } \\
\downarrow \text { Cognitive flexibility } \\
\downarrow \text { Psychomotor speed } \\
\uparrow \text { Verbal abilities }\end{array}$ \\
\hline Gillen et al. (55) & Adult abstinent users & $\begin{array}{l}\downarrow \text { Visual memory } \\
\uparrow \text { Visual motor speed }\end{array}$ \\
\hline Robinson et al. (78) & $\begin{array}{l}\text { Adult chronic cocaine } \\
\text { users } \\
\text { Adult chronic } \\
\text { cocaine + alcohol users }\end{array}$ & $\begin{array}{l}\downarrow \text { Psychomotor } \\
\text { functioning } \\
\downarrow \text { Global } \\
\text { neuropsychological } \\
\text { functioning }\end{array}$ \\
\hline Bolla et al. (8) & Adult abstinent users & $\begin{array}{l}\downarrow \text { Visuoperception } \\
\downarrow \text { Executive function } \\
\downarrow \text { Psychomotor speed } \\
\downarrow \text { Manual dexterity }\end{array}$ \\
\hline Aharonovich et al. (79) & Adult chronic users & $\begin{array}{l}\downarrow \text { Attention } \\
\downarrow \text { Memory } \\
\downarrow \text { Spatial ability }\end{array}$ \\
\hline Colzato et al. (73) & Adult recreational users & $\downarrow$ Inhibitory control \\
\hline Woicik et al. (80) & Adult chronic users & $\begin{array}{l}\downarrow \text { Verbal memory } \\
\downarrow \text { Executive function } \\
\downarrow \text { Attention }\end{array}$ \\
\hline Kalapatapu et al. (81) & $\begin{array}{l}\text { Young adult chronic users } \\
\text { Old adult chronic users }\end{array}$ & $\begin{array}{l}\downarrow \text { Psychomotor speed } \\
\downarrow \text { Attention } \\
\downarrow \text { Memory }\end{array}$ \\
\hline Madoz-Gúrpide et al. (82) & Adult chronic users & $\downarrow$ Executive function \\
\hline Soar et al. (83) & Adult recreational users & $\begin{array}{l}\downarrow \text { Executive function } \\
\downarrow \text { Attention }\end{array}$ \\
\hline Vonmoos et al. (84) & $\begin{array}{l}\text { Adult chronic users } \\
\text { Adult recreational users }\end{array}$ & $\begin{array}{l}\downarrow \text { Executive function } \\
\downarrow \text { Attention } \\
\downarrow \text { Working memory } \\
\downarrow \text { Declarative memory }\end{array}$ \\
\hline Winhusen et al. (68) & Adult chronic users & $\begin{array}{l}\downarrow \text { Executive function } \\
\downarrow \text { Inhibitory control } \\
\uparrow \text { Apathy }\end{array}$ \\
\hline Jones et al. (72) & Adult chronic users & $\begin{array}{l}\downarrow \text { Context processing } \\
\text { ability }\end{array}$ \\
\hline Preller et al. (85) & Adult chronic users & $\downarrow$ Empathy \\
\hline
\end{tabular}

$\downarrow$, Cognitive deficits; $\uparrow$, cognitive improvement; $\uparrow$, neurobehavioral symptoms.

example, a recent study by Preller et al. (87) suggests a relationship between social cognition test outcomes in cocaine-dependent patients and real-life social functioning. Specifically, participants showing more empathy and better mental processing abilities had a larger social network. In addition, social network size was correlated with duration and amount of cocaine use. This suggests that cocaine use and the associated altered empathy and insight may have consequences in everyday life, including fewer social contacts and deprivation of emotional support (87). Additionally, Preller et al. (85) also reported that individuals with cocaine dependence have blunted reward responses to social interactions as well as having reduced orbitofrontal cortex signals while performing a social cognition test. Taken together, these observations suggest that the treatment armamentarium may need to include interventions that boost more interactions of patients with other individuals in various social networks. This argument may explain, in part, why the affiliation-promoting peptide, oxytocin, may have beneficial effects in substance use treatment $(96,97)$. The possibility that social reward deficits might precede or be consequent to cocaine use needs to be investigated further (96).

In summary, although these cocaine-associated changes in cognitive functions have been well documented, their biological substrates have yet to be understood. Recent functional and structural imaging data provide ample support for impaired connectivity in frontostriatal $(4,98)$ and striatal-insular $(99)$ connections that serve as neuroanatomical and functional substrates for some of the cognitive deficits reported in cocaine using individuals. A clinical approach that takes into consideration the fact that some patients may actually suffer from cognitive impairments should stimulate investigations in order to provide more details on the basic substrates of cocaine use by humans (74).

\section{METHAMPHETAMINE USE}

Methamphetamine use is a serious public health problem (100). Long-term exposure to the drug has been shown to cause severe neurotoxic and neuropathological effects with consequent disturbances in several cognitive domains (1). These neuropsychological impairments that can impact the daily lives of METH users are detailed below.

\section{Neuropsychological Findings}

Chronic METH users show mild signs of cognitive decline (10) affecting a broad range of cognitive functions [Ref. (5, 6, 101-112), see details in Table 5; but see also Ref. (113) for a counterargument]. A meta-analysis study by Scott et al. (107) identified significant deficits of a medium magnitude in several different cognitive processes that are dependent on the functions of frontostriatal and limbic circuits. The affected domains include episodic memory, executive functions, complex information processing speed, and psychomotor functions (107). Additionally, METH use often results in irritability, agitation, and numerous other forms of psychiatric distress probably related to the myriad of interpersonal problems experienced by these patients $(114,115)$. METH dependence is also associated with complaints of cognitive dysfunctions including memory problems and self-reported deficits in everyday functioning (110). Additionally, impulsive behaviors may exacerbate their psychosocial difficulties and promote maintenance of drug-seeking behaviors, especially, by those who use large amounts of the drug $(116,117)$. The nature and magnitude of cognitive deficits associated with chronic 
TABLE 4 | Functional neuroimaging studies on cocaine users performing cognitive tasks.

\begin{tabular}{|c|c|c|c|}
\hline Reference & Cocaine dependence & Neuroimaging method & Main findings \\
\hline Goldstein et al. (59) & Adult chronic users & [(18)FDG PET] & $\begin{array}{l}\downarrow \text { Visual memory } \\
\downarrow \text { Verbal memory } \\
\downarrow \text { Executive function } \\
\downarrow \text { Attention } \\
\text { Differential DLPC and ACC metabolism }\end{array}$ \\
\hline Tucker et al. (60) & Adult abstinent users & SPECT & $\begin{array}{l}\downarrow \text { Decision-making } \\
\uparrow \text { Hyperperfusion in frontal cingulate and superior frontal gyrus }\end{array}$ \\
\hline Kübler et al. (61) & Adult chronic users & fMRI & $\begin{array}{l}\downarrow \text { Visuospatial working memory } \\
\downarrow \text { Verbal working memory } \\
\downarrow \text { Activation in prefrontal cortex, ACC, thalamus, and striatal areas }\end{array}$ \\
\hline Tomasi et al. (62) & Adult chronic users & $\mathrm{fMRI}$ & $\begin{array}{l}\downarrow \text { Working memory } \\
\downarrow \text { Activation in thalamus and mesencephalon } \\
\uparrow \text { Activation in frontal/parietal cortex } \\
\uparrow \text { Deactivation in putamen, ACC, parahippocampal gyrus, and amygdala }\end{array}$ \\
\hline Volkow et al. (86) & Adult chronic users & [(18)FDG PET] & $\downarrow$ Metabolic activity in NAcc and OFC when inhibit craving \\
\hline Hanlon et al. (63) & Adult chronic users & $\mathrm{fMRI}$ & $\begin{array}{l}\downarrow \text { Sensorimotor abilities } \\
\downarrow \text { Functional laterality in cortical motor areas }\end{array}$ \\
\hline Moeller et al. (64) & Adult abstinent users & $\mathrm{fMRI}$ & $\begin{array}{l}\downarrow \text { Activation in PFC, striatum, and thalamus } \\
\downarrow \text { Activation in thalamus associated with poor treatment response }\end{array}$ \\
\hline Volkow et al. (65) & $\begin{array}{l}\text { Adult male and female chronic } \\
\text { users }\end{array}$ & {$[(18) F D G$ PET $]$} & $\begin{array}{l}\uparrow \text { Brain reactivity to cocaine-cues in women } \\
\downarrow \text { Activation in frontal, cingulate, and parietal cortex, thalamus, and } \\
\text { midbrain in women }\end{array}$ \\
\hline Camchong et al. (66) & Adult chronic users & $\mathrm{fMRl}$ & $\begin{array}{l}\downarrow \text { Delay rewards } \\
\downarrow \text { Decision-making } \\
\downarrow \text { Learning } \\
\text { Altered connectivity within the ACC network, frontal hyperconnectivity }\end{array}$ \\
\hline $\begin{array}{l}\text { Barrós-Loscertales et al. } \\
\text { (67) }\end{array}$ & Adult chronic users & $\mathrm{fMRI}$ & $\downarrow$ Activation in PFC \\
\hline Preller et al. (87) & Adult chronic users & $\mathrm{fMRl}$ & $\downarrow$ Activation in OFC \\
\hline
\end{tabular}

ACC, anterior cingulate cortex; DLPC, dorsal lateral prefrontal cortex; NAcc, nucleus accumbens; OFC, orbitofrontal cortex; PFC, prefrontal cortex; $\downarrow$, decreased brain activation; $\uparrow$, increased brain activation; $\downarrow$, cognitive deficits.

METH use increase the risk of poorer health outcomes, high-risk behaviors, treatment non-adherence, and repeated relapses (110, 118). These adverse consequences might be secondary to poor executive function and memory deficits that may contribute to continuous drug-seeking behaviors (70). It needs to be noted that partial recovery of neuropsychological functioning and improvement in affective distress can be achieved after a period of sustained abstinence from METH (5). Hart et al. (113) have reviewed the literature and suggested that the deficits reported may be statistically but not clinically significant. In a follow-up analysis of similar data, Dean et al. (10) came to a different conclusion. These issues are important to clinicians who are responsible for the daily and/or long-term care of patients because small deficits may be of substantial importance when it comes to patients being able to follow instructions that would help them to participate in their own care, given the high rate of recidivism in that patient population $(119,120)$. Therefore, identifying patients with neuropsychological deficits would allow for the development of specific cognitive or pharmacological approaches that would benefit them.

Neuroimaging studies have documented several alterations in brain activation patterns induced by METH [Ref. (104, 121-128), see Table 6]. These studies reported decreased frontal activation associated with impaired decision-making (104) and cognitive control (127). Other brain regions sensitive to METH effects include the cingulate gyrus and insula $(122,128)$. METH users who showed impaired attention (122) and impaired cognitive control (128) exhibited abnormalities in these brain regions (see Table 6). It is worth mentioning that, in some cases, stimulantdependent patients report clinically significant neuropsychological abnormalities prior to lifetime initiation of psychostimulant use (68).

\section{Recovery of Neurocognitive Functioning and Treatment Implications}

Chronic use of several illicit drugs is associated with variable degrees of impaired cognitive functioning that shows different levels of improvement during sustained abstinence (3). Recovery from METH dependence is associated with improved performance in tests of mental flexibility, attention, processing speed, verbal memory, fine motor functioning, and verbal fluency (5). Improvements in performance are also seen in abstinent marijuana users $(13,14)$. Moreover, Brewer et al. (131) found that activation in corticostriatal regions, linked to cognitive control, correlated with abstinence and cocaine-free urine toxicology (131). There was also an inverse correlation between prefrontal cortex activation and treatment retention (131), thus supporting the notion that identification of patients with cognitive deficits are important for the long-term care of these patients $(3,132)$. This suggestion is supported by the results of a very recent report that strength of craving for METH can be reduced by cognitive strategies (133). In 
TABLE 5 | Cognitive deficits reported in methamphetamine users.

\begin{tabular}{|c|c|c|}
\hline Reference & $\begin{array}{l}\text { Methamphetamine } \\
\text { dependence }\end{array}$ & Cognitive findings \\
\hline Simon et al. (101) & Adult chronic users & $\begin{array}{l}\downarrow \text { Attention } \\
\downarrow \text { Verbal memory } \\
\downarrow \text { Executive function }\end{array}$ \\
\hline Simon et al. (102) & Adult chronic users & $\begin{array}{l}\downarrow \text { Psychomotor speed } \\
\downarrow \text { Attention } \\
\downarrow \text { Inhibitory control }\end{array}$ \\
\hline Salo et al. (105) & Adult abstinent users & $\downarrow$ Cognitive inhibition \\
\hline Simon et al. (103) & $\begin{array}{l}\text { Adult abstinent users } \\
\text { Adult abstinent users } \\
\text { with relapse } \\
\text { Adult chronic users }\end{array}$ & $\downarrow$ Episodic memory \\
\hline $\begin{array}{l}\text { Newton et al. } \\
(106)\end{array}$ & Adult abstinent users & $\begin{array}{l}\downarrow \text { Working memory } \\
\downarrow \text { Psychomotor speed }\end{array}$ \\
\hline Scott et al. (107) & $\begin{array}{l}\text { Adult chronic users } \\
\text { meta-analysis }\end{array}$ & $\begin{array}{l}\downarrow \text { Executive function } \\
\downarrow \text { Verbal fluency } \\
\downarrow \text { Motor ability } \\
\downarrow \text { Verbal memory } \\
\downarrow \text { Language } \\
\downarrow \text { Visuo-constructional abilities } \\
\downarrow \text { Information processing speed }\end{array}$ \\
\hline Rendell et al. (108) & Adult abstinent users & $\begin{array}{l}\downarrow \text { Executive function } \\
\downarrow \text { Working memory } \\
\downarrow \text { Retro and prospective memory }\end{array}$ \\
\hline Henry et al. (109) & Adult abstinent users & $\downarrow$ Facial recognition \\
\hline Henry et al. (110) & Adult abstinent users & $\downarrow$ Functioning everyday abilities \\
\hline ludicello et al. (5) & $\begin{array}{l}\text { Adult abstinent users, } \\
\text { w or w/o relapse } \\
\text { Longitudinal study }\end{array}$ & $\begin{array}{l}\uparrow \text { Global cognitive and affective } \\
\text { improvements with sustained } \\
\text { abstinence }\end{array}$ \\
\hline Weber et al. (111) & Adult abstinent users & $\begin{array}{l}\downarrow \text { Global cognitive } \\
\text { scores = predictor of } \\
\text { unemployment }\end{array}$ \\
\hline Cattie et al. (112) & Adult abstinent users & $\begin{array}{l}\uparrow \text { Neurobehavioral symptoms } \\
\downarrow \text { Inhibition (self-reported) } \\
\downarrow \text { Executive function } \\
\text { (self-reported) }\end{array}$ \\
\hline
\end{tabular}

$\downarrow$, Cognitive deficits; $\uparrow$, cognitive improvement; $\uparrow$, neurobehavioral symptoms.

addition, patients who participated in computer-assisted cognitive behavioral therapy showed improved task performance and reduced task-related signal changes in several regions implicated in cognitive control, impulse control, and motivational salience, including the anterior cingulate and midbrain (134).

\section{CONCLUSION}

Chronic use of illicit substances, including marijuana, cocaine, and METH, is associated with abnormal goal-directed behaviors that are thought to be the manifestations of altered corticostriatal-limbic circuits $(2,135)$. Nevertheless, the wealth of clinical presentations, neuroimaging studies, and some pathological findings suggest that the biochemical and structural effects of chronic heavy use of drugs may reach beyond the boundaries of these reward circuits (1). The data reviewed here indicate that chronic use of illicit drugs is accompanied by moderate
TABLE 6 | Functional neuroimaging studies on methamphetamine users performing cognitive tasks.

\begin{tabular}{|c|c|c|c|}
\hline Reference & $\begin{array}{l}\text { Methamphetamine } \\
\text { dependence }\end{array}$ & $\begin{array}{l}\text { Neuroimaging } \\
\text { method }\end{array}$ & Main findings \\
\hline $\begin{array}{l}\text { Paulus et al. } \\
(104)\end{array}$ & Adult abstinent users & fMRI & $\begin{array}{l}\downarrow \text { Decision-making } \\
\downarrow \text { Activation in PFC }\end{array}$ \\
\hline $\begin{array}{l}\text { Chang et al. } \\
(121)\end{array}$ & Adult chronic users & Structural MRI & $\begin{array}{l}\text { Larger globus } \\
\text { pallidus and } \\
\text { putamen }\end{array}$ \\
\hline $\begin{array}{l}\text { London } \\
\text { et al. (122) }\end{array}$ & Adult abstinent users & [(18)FDG PET] & $\begin{array}{l}\downarrow \text { Attention } \\
\text { Differential } \\
\text { activation in } \\
\text { cingulate gyrus } \\
\text { and the insula }\end{array}$ \\
\hline $\begin{array}{l}\text { Johanson } \\
\text { et al. (123) }\end{array}$ & Adult abstinent users & PET & $\begin{array}{l}\downarrow \text { Memory } \\
\downarrow \text { Attention } \\
\downarrow \text { Information } \\
\text { processing speed } \\
\downarrow \text { DAT and VMAT2 } \\
\text { in striatal regions }\end{array}$ \\
\hline $\begin{array}{l}\text { Monterosso } \\
\text { et al. (124) }\end{array}$ & Adult abstinent users & $\mathrm{fMRI}$ & $\begin{array}{l}\downarrow \text { Decision-making } \\
\downarrow \text { Cortical } \\
\text { efficiency in } \\
\text { frontoparietal } \\
\text { clusters }\end{array}$ \\
\hline $\begin{array}{l}\text { Payer et al. } \\
(129)\end{array}$ & Adult abstinent users & fMRI & $\begin{array}{l}\uparrow \text { Activation in } \\
\text { ACC } \\
\downarrow \text { Activation in PFC }\end{array}$ \\
\hline $\begin{array}{l}\text { Hoffman } \\
\text { et al. (130) }\end{array}$ & Adult abstinent users & $\mathrm{fMRI}$ & $\begin{array}{l}\uparrow \text { Impulsivity } \\
\downarrow \text { Activation in } \\
\text { caudate, DLPC, } \\
\text { ACC }\end{array}$ \\
\hline $\begin{array}{l}\text { Salo et al. } \\
(127)\end{array}$ & Adult abstinent users & $\mathrm{fMRI}$ & $\begin{array}{l}\downarrow \text { Cognitive control } \\
\downarrow \text { Activation in PFC }\end{array}$ \\
\hline $\begin{array}{l}\text { Nestor et al. } \\
(128)\end{array}$ & Adult abstinent users & $\mathrm{fMRI}$ & $\begin{array}{l}\downarrow \text { Cognitive control } \\
\downarrow \text { Activation in } \\
\text { motor cortex/ } \\
\text { anterior cingulate } \\
\text { gyrus, insular } \\
\text { cortex }\end{array}$ \\
\hline
\end{tabular}

ACC, anterior cingulate cortex; DLPC, dorsal lateral prefrontal cortex; PFC, prefrontal cortex; $\downarrow$, decreased brain activation; $\uparrow$, increased brain activation; $\downarrow$, cognitive deficits; $\uparrow$, cognitive improvement; $\uparrow$, neurobehavioral symptoms.

cognitive impairments in some patients. These observations may be related to functional and structural changes in various brain regions, including both cortical and subcortical regions of the human brain $(1,98,136)$. In addition, it has been reported frontal deficits in psychostimulant-dependent patients reporting current clinically neurobehavioral abnormalities may be linked to pre-existing abnormalities (68). Because drug dependence develop over many months, it is likely that drug-related changes of behaviors may be modulated by some of these pathological phenomena in such a way as to significantly impact the clinical course of chronic use of these substances. Thus, impaired learning and memory functions might negatively impact the ability of a specific subset of patients to benefit from general treatment approaches. This inability may explain, in part, the high rate of recidivism in this patient population. This argument suggests that 
approaches to these individuals should take into consideration the diversity of patterns of substance use and clinical presentations. This argument suggests that thorough neuropsychological and neuroimaging assessments should be undertaken to identify these subsets of drug users. This approach should help to dichotomize patients as being unimpaired or impaired, with specific cognitive and pharmacological treatments targeting subgroups of patients. Present approaches that group all patients together

\section{REFERENCES}

1. Cadet JL, Bisagno V, Milroy CM. Neuropathology of substance use disorders. Acta Neuropathol (2014) 127:91-107. doi:10.1007/s00401-013-1221-7

2. Volkow ND, Wang G-J, Fowler JS, Tomasi D. Addiction circuitry in the human brain. Annu Rev Pharmacol Toxicol (2012) 52:321-36. doi:10.1146/ annurev-pharmtox-010611-134625

3. Schulte MH, Cousijn J, den Uyl TE, Goudriaan AE, van den Brink W, Veltman DJ, et al. Recovery of neurocognitive functions following sustained abstinence after substance dependence and implications for treatment. Clin Psychol Rev (2014) 34:531-50. doi:10.1016/j.cpr.2014.08.002

4. Ersche KD, Turton AJ, Chamberlain SR, Müller U, Bullmore ET, Robbins TW. Cognitive dysfunction and anxious-impulsive personality traits are endophenotypes for drug dependence. Am J Psychiatry (2012) 169:926-36. doi:10.1176/appi.ajp.2012.11091421

5. Iudicello JE, Woods SP, Vigil O, Scott JC, Cherner M, Heaton RK, et al. Longer term improvement in neurocognitive functioning and affective distress among methamphetamine users who achieve stable abstinence. $J$ Clin Exp Neuropsychol (2010) 32:704-18. doi:10.1080/13803390903512637

6. Kalechstein AD, Newton TF, Green M. Methamphetamine dependence is associated with neurocognitive impairment in the initial phases of abstinence. J Neuropsychiatry Clin Neurosci (2003) 15:215-20. doi:10.1176/jnp.15.2.215

7. Garavan H, Stout JC. Neurocognitive insights into substance abuse. Trends Cogn Sci (2005) 9:195-201. doi:10.1016/j.tics.2005.02.008

8. Bolla KI, Rothman R, Cadet JL. Dose-related neurobehavioral effects of chronic cocaine use. J Neuropsychiatry Clin Neurosci (1999) 11:361-9. doi:10.1176/jnp.11.3.361

9. Bolla KI, Brown K, Eldreth D, Tate K, Cadet JL. Dose-related neurocognitive effects of marijuana use. Neurology (2002) 59:1337-43. doi:10.1212/01. WNL.0000031422.66442.49

10. Dean AC, Groman SM, Morales AM, London ED. An evaluation of the evidence that methamphetamine abuse causes cognitive decline in humans. Neuropsychopharmacology (2013) 38:259-74. doi:10.1038/npp.2012.179

11. Weinborn M, Moyle J, Bucks RS, Stritzke W, Leighton A, Woods SP. Time-based prospective memory predicts engagement in risk behaviors among substance users: results from clinical and nonclinical samples. J Int Neuropsychol Soc (2013) 19:284-94. doi:10.1017/S1355617712001361

12. UNODC 2013 World Drug Report. (2013). Available from: https://www. unodc.org/unodc/secured/wdr/wdr2013/World_Drug_Report_2013.pdf

13. Pope HG, Gruber AJ, Hudson JI, Huestis MA, Yurgelun-Todd D. Neuropsychological performance in long-term cannabis users. Arch Gen Psychiatry (2001) 58:909-15. doi:10.1001/archpsyc.58.10.909

14. Pope HG Jr, Gruber AJ, Yurgelun-Todd D. Residual neuropsychologic effects of cannabis. Curr Psychiatry Rep (2001) 3:507-12. doi:10.1007/ s11920-001-0045-7

15. Block RI, O’Leary DS, Hichwa RD, Augustinack JC, Boles Ponto LL, Ghoneim MM, et al. Effects of frequent marijuana use on memory-related regional cerebral blood flow. Pharmacol Biochem Behav (2002) 72:237-50. doi:10.1016/S0091-3057(01)00771-7

16. Abdullaev Y, Posner MI, Nunnally R, Dishion TJ. Functional MRI evidence for inefficient attentional control in adolescent chronic cannabis abuse. Behav Brain Res (2010) 215:45-57. doi:10.1016/j.bbr.2010.06.023

17. Bolla KI, Eldreth D, Matochik J, Cadet JL. Neural substrates of faulty decision-making in abstinent marijuana users. Neuroimage (2005) 26:480-92. doi:10.1016/j.neuroimage.2005.02.012

18. King GR, Ernst T, Deng W, Stenger A, Gonzales RM, Nakama H, et al. Altered brain activation during visuomotor integration in chronic active need to be revamped to allow for more rational and data-driven approaches to treatment.

\section{FUNDING}

The Intramural Research Program of the National Institute on Drug Abuse, NIH, and DHHS supports JC. VB is supported by a grant from ANPCyT, PICT 2012-0924, Argentina.

cannabis users: relationship to cortisol levels. J Neurosci (2011) 31:17923-31 doi:10.1523/JNEUROSCI.4148-11.2011

19. Colizzi M, Fazio L, Ferranti L, Porcelli A, Masellis R, Marvulli D, et al. Functional genetic variation of the cannabinoid receptor 1 and cannabis use interact on prefrontal connectivity and related working memory behavior. Neuropsychopharmacology (2015) 40:640-9. doi:10.1038/npp.2014.213

20. Fried PA, Watkinson B, Gray R. Neurocognitive consequences of marihuana - a comparison with pre-drug performance. Neurotoxicol Teratol (2005) 27:231-9. doi:10.1016/j.ntt.2004.11.003

21. Solowij N, Michie PT, Fox AM. Differential impairments of selective attention due to frequency and duration of cannabis use. Biol Psychiatry (1995) 37:731-9. doi:10.1016/0006-3223(94)00178-6

22. Solowij N, Stephens RS, Roffman RA, Babor T, Kadden R, Miller M, et al. Cognitive functioning of long-term heavy cannabis users seeking treatment. JAMA (2002) 287(13):1123-31. Erratum in: JAMA (2002) 287:1651.

23. Lyons MJ, Bar JL, Panizzon MS, Toomey R, Eisen S, Xian H, et al. Neuropsychological consequences of regular marijuana use: a twin study. Psychol Med (2004) 34:1239-50. doi:10.1017/S0033291704002260

24. Medina KL, McQueeny T, Nagel BJ, Hanson KL, Yang TT, Tapert SF. Prefrontal cortex morphometry in abstinent adolescent marijuana users: subtle gender effects. Addict Biol (2009) 14:457-68. doi:10.1111/j.1369-1600.2009.00166.x

25. Hanson KL, Winward JL, Schweinsburg AD, Medina KL, Brown SA, Tapert SF. Longitudinal study of cognition among adolescent marijuana users over three weeks of abstinence. Addict Behav (2010) 35:970-6. doi:10.1016/j. addbeh.2010.06.012

26. Battisti RA, Roodenrys S, Johnstone SJ, Respondek C, Hermens DF, Solowij N. Chronic use of cannabis and poor neural efficiency in verbal memory ability. Psychopharmacology (2010) 209:319-30. doi:10.1007/s00213-010-1800-4

27. Griffith-Lendering MFH, Huijbregts SCJ, Vollebergh WAM, Swaab H. Motivational and cognitive inhibitory control in recreational cannabis users. J Clin Exp Neuropsychol (2012) 34:688-97. doi:10.1080/13803395.2012.668 874

28. Meier MH, Caspi A, Ambler A, Harrington H, Houts R, Keefe RS, et al. Persistent cannabis users show neuropsychological decline from childhood to midlife. Proc Natl Acad Sci U S A (2012) 109:E2657-64. doi:10.1073/ pnas.1206820109

29. Solowij N, Jones KA, Rozman ME, Davis SM, Ciarrochi J, Heaven PC, et al. Reflection impulsivity in adolescent cannabis users: a comparison with alcohol-using and non-substance-using adolescents. Psychopharmacology (2012) 219:575-86. doi:10.1007/s00213-011-2486-y

30. Sewell RA, Schnakenberg A, Elander J, Radhakrishnan R, Williams A, Skosnik PD, et al. Acute effects of THC on time perception in frequent and infrequent cannabis users. Psychopharmacology (Berl) (2013) 226:401-13. doi:10.1007/s00213-012-2915-6

31. Chang L, Yakupov R, Cloak C, Ernst T. Marijuana use is associated with a reorganized visual-attention network and cerebellar hypoactivation. Brain (2006) 129:1096-112. doi:10.1093/brain/awl064

32. Padula CB, Schweinsburg AD, TapertSF. Spatialworkingmemoryperformance and $\mathrm{fMRI}$ activation interaction in abstinent adolescent marijuana users. Psychol Addict Behav (2007) 21:478-87. doi:10.1037/0893-164X.21.4.478

33. Tapert SF, Schweinsburg AD, Drummond SPA, Paulus MP, Brown SA, Yang TT. Functional MRI of inhibitory processing in abstinent adolescent marijuana users. Psychopharmacology (2007) 194:173-83. doi:10.1007/ s00213-007-0823-y

34. Schweinsburg AD, Nagel BJ, Schweinsburg BC, Park A, Theilmann RJ, Tapert SF. Abstinent adolescent marijuana users show altered $\mathrm{fMRI}$ response during 
spatial working memory. Psychiatry Res (2008) 163:40-51. doi:10.1016/j. pscychresns.2007.04.018

35. Hester R, Nestor L, Garavan H. Impaired error awareness and anterior cingulate cortex hypoactivity in chronic cannabis users. Neuropsychopharmacology (2009) 34:2450-8. doi:10.1038/npp.2009.67

36. Hanlon CA, Dufault DL, Wesley MJ, Porrino LJ. Elevated gray and white matter densities in cocaine abstainers compared to current users. Psychopharmacology (2011) 218:681-92. doi:10.1007/s00213-011-2360-y

37. Wesley MJ, Hanlon CA, Porrino LJ. Poor decision-making by chronic marijuana users is associated with decreased functional responsiveness to negative consequences. Psychiatry Res (2011) 191:51-9. doi:10.1016/j. pscychresns.2010.10.002

38. Harding IH, Solowij N, Harrison BJ, Takagi M, Lorenzetti V, Lubman DI, et al. Functional connectivity in brain networks underlying cognitive control in chronic cannabis users. Neuropsychopharmacology (2012) 37:1923-33. doi:10.1038/npp.2012.39

39. Schuster RM, Crane NA, Mermelstein R, Gonzalez R. The influence of inhibitory control and episodic memory on the risky sexual behavior of young adult cannabis users. J Int Neuropsychol Soc (2012) 18:827-33. doi:10.1016/j. biopsych.2008

40. Bossong MG, Niesink RJM. Adolescent brain maturation, the endogenous cannabinoid system and the neurobiology of cannabis-induced schizophrenia. Prog Neurobiol (2010) 92:370-85. doi:10.1016/j. pneurobio.2010.06.010

41. Hall W, Degenhardt L. Adverse health effects of non-medical cannabis use. Lancet (2009) 374:1383-91. doi:10.1016/S0140-6736(09)61037-0

42. Moore THM, Zammit S, Lingford-Hughes A, Barnes TR, Jones PB, Burke $\mathrm{M}$, et al. Cannabis use and risk of psychotic or affective mental health outcomes: a systematic review. Lancet (2007) 370:319-28. doi:10.1016/ S0140-6736(07)61162-3

43. Bhattacharyya S, Crippa JA, Allen P, Martin-Santos R, Borgwardt S, Fusar-Poli $\mathrm{P}$, et al. Induction of psychosis by $\Delta 9$-tetrahydrocannabinol reflects modulation of prefrontal and striatal function during attentional salience processing. Arch Gen Psychiatry (2012) 69:27-36. doi:10.1001/ archgenpsychiatry.2011.161

44. Pertwee RG. Ligands that target cannabinoid receptors in the brain: from THC to anandamide and beyond. Addict Biol (2008) 13:147-59. doi:10.1111/j.1369-1600.2008.00108.x

45. Parsons LH, Hurd YL. Endocannabinoid signalling in reward and addiction. Nat Rev Neurosci (2015) 16:579-94. doi:10.1038/nrn4004

46. Chadwick B, Miller ML, Hurd YL. Cannabis use during adolescent development: susceptibility to psychiatric illness. Front Psychiatry (2013) 4:129. doi:10.3389/fpsyt.2013.00129

47. Di Forti M, Morgan C, Dazzan P, Pariante C, Mondelli V, Marques TR, et al. High-potency cannabis and the risk of psychosis. Br J Psychiatry (2009) 195:488-91. doi:10.1192/bjp.bp.109.064220

48. Morgan CJA, Curran HV. Effects of cannabidiol on schizophrenia-like symptoms in people who use cannabis. Br J Psychiatry (2008) 192:306-7. doi:10.1192/bjp.bp.107.046649

49. McQueeny T, Padula CB, Price J, Medina KL, Logan P, Tapert SF. Gender effects on amygdala morphometry in adolescent marijuana users. Behav Brain Res (2011) 224:128-34. doi:10.1016/j.bbr.2011.05.031

50. Colzato LS, Hommel B. Recreational use of cocaine eliminates inhibition of return. Neuropsychology (2009) 23:125-9. doi:10.1037/a0013821

51. Volkow ND, Wang GJ, Fowler JS, Tomasi D. Addiction circuitry in the human brain. Annu Rev Pharmacol Toxicol (2012) 52:321-36. doi:10.1146/ annurev-pharmtox-010611-134625

52. Ardila A, Rosselli M, Strumwasser S. Neuropsychological deficits in chronic cocaine abusers. Int $J$ Neurosci (1991) 7:73-9. doi: $10.3109 / 00207459109150348$

53. O'Malley S, Adamse M, Heaton RK, Gawin FH. Neuropsychological impairment in chronic cocaine abusers. Am J Drug Alcohol Abuse (1992) 18:131-44. doi:10.3109/00952999208992826

54. Hoff AL, Riordan H, Morris L, Cestaro V, Wieneke M, Alpert R, et al. Effects of crack cocaine on neurocognitive function. Psychiatry Res (1996) 60:167-76. doi:10.1016/0165-1781(96)02758-8

55. Gillen RW, Kranzler HR, Bauer LO, Burleson JA, Samarel D, Morrison DJ. Neuropsychologic findings in cocaine-dependent outpatients. Prog
Neuropsychopharmacol Biol Psychiatry (1998) 22:1061-76. doi:10.1016/ S0278-5846(98)00057-8

56. Rosselli M, Ardila A, Lubomski M, Murray S, King K. Personality profile and neuropsychological test performance in chronic cocaine-abusers. Int $J$ Neurosci (2001) 110:55-72. doi:10.3109/00207450108994221

57. Mittenberg W, Motta S. Effects of chronic cocaine abuse on memory and learning. Arch Clin Neuropsychol (1993) 8:477-83. doi:10.1016/0887-6177(93)90048-6

58. Smelson DA, Roy A, Santana S, Engelhart C. Neuropsychological deficits in withdrawn cocaine-dependent males. Am J Drug Alcohol Abuse (1999) 25:377-81. doi:10.1081/ADA-100101867

59. Goldstein RZ, Leskovjan AC, Hoff AL, Hitzemann R, Bashan F, Khalsa SS, et al. Severity of neuropsychological impairment in cocaine and alcohol addiction: association with metabolism in the prefrontal cortex. Neuropsychologia (2004) 42:1447-58. doi:10.1016/j.neuropsychologia.2004.04.002

60. Tucker KA, Potenza MN, Beauvais JE, Browndyke JN, Gottschalk PC, Kosten TR. Perfusion abnormalities and decision making in cocaine dependence. Biol Psychiatry (2004) 56:527-30. doi:10.1016/j.biopsych.2004.06.031

61. Kübler A, Murphy K, Garavan H. Cocaine dependence and attention switching within and between verbal and visuospatial working memory. Eur J Neurosci (2005) 21:1984-92. doi:10.1111/j.1460-9568.2005.04027.x

62. Tomasi D, Goldstein RZ, Telang F, Maloney T, Alia-Klein N, Caparelli EC, et al. Widespread disruption in brain activation patterns to a working memory task during cocaine abstinence. Brain Res (2007) 1171:83-92. doi:10.1016/j. brainres.2007.06.102

63. Hanlon CA, Wesley MJ, Roth AJ, Miller MD, Porrino LJ. Loss of laterality in chronic cocaine users: an fMRI investigation of sensorimotor control. Psychiatry Res (2010) 181:15-23. doi:10.1016/j.pscychresns.2009.07.009

64. Moeller FG, Steinberg JL, Schmitz JM, Ma L, Liu S, Kjome KL. Working memory fMRI activation in cocaine-dependent subjects: association with treatment response. Psychiatry Res (2010) 181:174-82. doi:10.1016/j. pscychresns.2009.11.003

65. Volkow ND, Tomasi D, Wang G-J, Fowler JS, Telang F, Goldstein RZ, et al. Reduced metabolism in brain "control networks" following cocaine-cues exposure in female cocaine abusers. PLoS One (2011) 6:e16573. doi:10.1371/ journal.pone.0016573

66. Camchong J, MacDonald AW, Nelson B, Bell C, Mueller BA, Specker S, et al. Frontal hyperconnectivity related to discounting and reversal learning in cocaine subjects. Biol Psychiatry (2011) 69:1117-23. doi:10.1016/j. biopsych.2011.01.008

67. Barrós-Loscertales A, Garavan H, Bustamante JC, Ventura-Campos N, Llopis $\mathrm{JJ}$, Belloch V, et al. Reduced striatal volume in cocaine-dependent patients. Neuroimage (2011) 56:1021-6. doi:10.1016/j.neuroimage.2011.02.035

68. Winhusen TM, Somoza EC, Lewis DF, Kropp FB, Horigian VE, Adinoff B. Frontal systems deficits in stimulant-dependent patients: evidence of pre-illness dysfunction and relationship to treatment response. Drug Alcohol Depend (2013) 127:94-100. doi:10.1016/j.drugalcdep.2012.06.017

69. Bolla KI, Cadet JL, London ED. The neuropsychiatry of chronic cocaine abuse. J Neuropsychiatry Clin Neurosci (1998) 10:280-9. doi:10.1176/jnp.10.3.280

70. Bechara A, Damasio AR, Damasio H, Anderson SW. Insensitivity to future consequences following damage to human prefrontal cortex. Cognition (1994) 50:7-15. doi:10.1016/0010-0277(94)90018-3

71. Bolla K, Ernst M, Kiehl K, Mouratidis M, Eldreth D, Contoreggi C. Prefrontal cortical dysfunction in abstinent cocaine abusers. J Neuropsychiatry Clin Neurosci (2004) 16:456-64. doi:10.1176/jnp.16.4.456

72. Jones JA, Lim KO, Wozniak JR, Specker S, MacDonald AW III. Contextprocessing abilities in chronic cocaine users. Psychol Addict Behav (2013) 27:687-95. doi:10.1037/a0032237

73. Colzato LS, Van den Wildenberg WPM, Hommel B. Impaired inhibitory control in recreational cocaine users. PLoS One (2007) 2:e1143. doi:10.1371/ journal.pone.0001143

74. Moreno-López L, Catena A, Fernández-Serrano MJ, Delgado-Rico E, Stamatakis EA, Pérez-García M, et al. Trait impulsivity and prefrontal gray matter reductions in cocaine dependent individuals. Drug Alcohol Depend (2012) 125:208-14. doi:10.1016/j.drugalcdep.2012.02.012

75. Colzato LS, Huizinga M, Hommel B. Recreational cocaine polydrug use impairs cognitive flexibility but not working memory. Psychopharmacology (2009) 207:225-34. doi:10.1007/s00213-009-1650-0 
76. Colzato LS, Van den Wildenberg WPM, Hommel B. Reduced attentional scope in cocaine polydrug users. PLoS One (2009) 4:e6043. doi:10.1371/ journal.pone.0006043

77. Strickland TL, Mena I, Villanueva-Meyer J, Miller BL, Cummings J, Mehringer CM, et al. Cerebral perfusion and neuropsychological consequences of chronic cocaine use. J Neuropsychiatry Clin Neurosci (1993) 5:419-27. doi:10.1176/jnp.5.4.419

78. Robinson JE, Heaton RK, O'Malley SS. Neuropsychological functioning in cocaine abusers with and without alcohol dependence. J Int Soc (1999) 5:10-9.

79. Aharonovich E, Hasin DS, Brooks AC, Liu X, Bisaga A, Nunes EV. Cognitive deficits predict low treatment retention in cocaine dependent patients. Drug Alcohol Depend (2006) 81:313-22. doi:10.1016/j.drugalcdep.2005.08.003

80. Woicik PA, Moeller SJ, Alia-Klein N, Maloney T, Lukasik TM, Yeliosof O, et al. The neuropsychology of cocaine addiction: recent cocaine use masks impairment. Neuropsychopharmacology (2009) 34:1112-22. doi:10.1038/ npp. 2008.60

81. Kalapatapu RK, Vadhan NP, Rubin E, Bedi G, Cheng WY, Sullivan $\mathrm{MA}$, et al. A pilot study of neurocognitive function in older and younger cocaine abusers and controls. Am J Addict (2011) 20:228-39. doi:10.1111/j.1521-0391.2011.00128.x

82. Madoz-Gúrpide A, Blasco-Fontecilla H, Baca-García E, Ochoa-Mangado E. Executive dysfunction in chronic cocaine users: an exploratory study. Drug Alcohol Depend (2011) 117:55-8. doi:10.1016/j.drugalcdep.2010.11.030

83. Soar K, Mason C, Potton A, Dawkins L. Neuropsychological effects associated with recreational cocaine use. Psychopharmacology (2012) 222:633-43. doi:10.1007/s00213-012-2666-4

84. Vonmoos M, Hulka LM, Preller KH, Jenni D, Baumgartner MR, Stohler R, et al. Cognitive dysfunctions in recreational and dependent cocaine users: role of attention-deficit hyperactivity disorder, craving and early age at onset. Br J Psychiatry (2013) 203:35-43. doi:10.1192/bjp.bp.112.118091

85. Preller KH, Hulka LM, Vonmoos M, Jenni D, Baumgartner MR, Seifritz $\mathrm{E}$, et al. Impaired emotional empathy and related social network deficits in cocaine users. Addict Biol (2014) 19:452-66. doi:10.1111/adb.12070

86. Volkow ND, Fowler JS, Wang G-J, Telang F, Logan J, Jayne M, et al. Cognitive control of drug craving inhibits brain reward regions in cocaine abusers. Neuroimage (2010) 49:2536-43. doi:10.1016/j.neuroimage.2009.10.088

87. Preller KH, Herdener M, Schilbach L, Stämpfli P, Hulka LM, Vonmoos M, et al. Functional changes of the reward system underlie blunted response to social gaze in cocaine users. Proc Natl Acad Sci U S A (2014) 111:2842-7. doi:10.1073/pnas.1317090111

88. Volkow ND, Fowler JS, Wang GJ, Hitzemann R, Logan J, Schlyer DJ. Decreased dopamine D2 receptor availability is associated with reduced frontal metabolism in cocaine abusers. Synapse (1993) 14:169-77. doi:10.1002/ syn. 890140210

89. Volkow ND, Wang GJ, Fischman MW, Foltin RW, Fowler JS, Abumrad $\mathrm{NN}$, et al. Relationship between subjective effects of cocaine and dopamine transporter occupancy. Nature (1997) 386:827-30. doi:10.1038/386827a0

90. Volkow ND, Fowler JS, Wang GJ. Imaging studies on the role of dopamine in cocaine reinforcement and addiction in humans. J Psychopharmacol (1999) 13:337-45. doi:10.1177/026988119901300406

91. Martinez D, Narendran R, Foltin RW, Slifstein M, Hwang DR, Broft A, et al. Amphetamine-induced dopamine release: markedly blunted in cocaine dependence and predictive of the choice to self-administer cocaine. Am J Psychiatry (2007) 164:622-9. doi:10.1176/ajp.2007.164.4.622

92. Martinez D, Greene K, Broft A, Kumar D, Liu F, Narendran R, et al. Lower level of endogenous dopamine in patients with cocaine dependence: findings from PET imaging of $\mathrm{D}(2) / \mathrm{D}(3)$ receptors following acute dopamine depletion. Am J Psychiatry (2009) 166:1170-7. doi:10.1176/appi.ajp.2009.08121801. Erratum in: Am J Psychiatry (2009) 166:1299.

93. Tomasi D, Volkow ND, Wang R, Carrillo JH, Maloney T, Alia-Klein N, et al. Disrupted functional connectivity with dopaminergic midbrain in cocaine abusers. PLoS One (2010) 5:e10815. doi:10.1371/journal.pone.0010815

94. Ernst T, Chang L, Oropilla G, Gustavson A, Speck O. Cerebral perfusion abnormalities in abstinent cocaine abusers: a perfusion MRI and SPECT study. Psychiatry Res (2000) 99:63-74. doi:10.1016/S0925-4927(00)00056-1

95. Herning RI, King DE, Better WE, Cadet JL. Neurovascular deficits in cocaine abusers. Neuropsychopharmacology (1999) 21:110-8. doi:10.1016/ S0893-133X(98)00141-9
96. Verdejo-Garcia A. Social cognition in cocaine addiction. Proc Natl Acad Sci US A (2014) 111:2406-7. doi:10.1073/pnas.1324287111

97. Bisagno V, Cadet JL. Stress, sex, and addiction: potential roles of corticotropin-releasing factor, oxytocin, and arginine-vasopressin. Behav Pharmacol (2014) 25:445-57. doi:10.1097/FBP.0000000000000049

98. Hu Y, Salmeron BJ, Gu H, Stein EA, Yang Y. Impaired functional connectivity within and between frontostriatal circuits and its association with compulsive drug use and trait impulsivity in cocaine addiction. JAMA Psychiatry (2015) 72:584-92. doi:10.1001/jamapsychiatry.2015.1

99. McHugh MJ, Demers CH, Braud J, Briggs R, Adinoff B, Stein EA. Striatalinsula circuits in cocaine addiction: implications for impulsivity and relapse risk. Am J Drug Alcohol Abuse (2013) 39:424-32. doi:10.3109/00952990.20 13.847446

100. Degenhardt L, Hall W. Extent of illicit drug use and dependence, and their contribution to the global burden of disease. Lancet (2012) 379:55-70 doi:10.1016/S0140-6736(11)61138-0

101. Simon SL, Domier C, Carnell J, Brethen P, Rawson R, Ling W. Cognitive impairment in individuals currently using methamphetamine. Am J Addict (2000) 9:222-31. doi:10.1080/10550490050148053

102. Simon SL, Domier CP, Sim T, Richardson K, Rawson RA, Ling W. Cognitive performance of current methamphetamine and cocaine abusers. J Addictive Dis (2002) 21:61-74. doi:10.1300/J069v21n01_06

103. Simon SL, Dacey J, Glynn S, Rawson R, Ling W. The effect of relapse on cognition in abstinent methamphetamine abusers. J Subst Abuse Treat (2004) 27:59-66. doi:10.1016/j.jsat.2004.03.011

104. Paulus MP, Hozack NE, Zauscher BE, Frank L, Brown GG, Braff DL. Behavioral and functional neuroimaging evidence for prefrontal dysfunction in methamphetamine-dependent subjects. Neuropsychopharmacology (2002) 26:53-63. doi:10.1016/S0893-133X(01)00334-7

105. Salo R, Nordahl TE, Possin K, Leamon M, Gibson DR, Galloway GP. Preliminary evidence of reduced cognitive inhibition in methamphetamine-dependent individuals. Psychiatry Res (2002) 111:65-74. doi:10.1016/ S0165-1781(02)00111-7

106. Newton TF, Kalechstein AD, Hardy DJ, Cook IA, Nestor L, Ling W, et al. Association between quantitative EEG and neurocognition in methamphetamine-dependent volunteers. Clin Neurophysiol (2004) 115:194-8. doi:10.1016/S1388-2457(03)00314-6

107. Scott JC, Woods SP, Matt GE, Meyer RA, Heaton RK, Atkinson JH, et al. Neurocognitive effects of methamphetamine: a critical review and meta-analysis. Neuropsychol Rev (2007) 17:275-97. doi:10.1007/ s11065-007-9031-0

108. Rendell PG, Mazur M, Henry JD. Prospective memory impairment in former users of methamphetamine. Psychopharmacology (2009) 203:609-16 doi:10.1007/s00213-008-1408-0

109. Henry JD, Mazur M, Rendell PG. Social-cognitive difficulties in former users of methamphetamine. Br J Clin Psychol (2009) 48:323-7. doi:10.1348/00071 2609X435742

110. Henry BL, Minassian A, Perry W. Effect of methamphetamine dependence on everyday functional ability. Addict Behav (2010) 35:593-8. doi:10.1016/j. addbeh.2010.01.013

111. Weber E, Blackstone K, Iudicello JE, Morgan EE, Grant I, Moore DJ. Neurocognitive deficits are associated with unemployment in chronic methamphetamine users. Drug Alcohol Depend (2012) 125:146-53. doi:10.1016/j. drugalcdep.2012.04.002

112. Cattie JE, Woods SP, Iudicello JE, Posada C, Grant I; TMARC Group. Elevated neurobehavioral symptoms are associated with everyday functioning problems in chronic methamphetamine users. J Neuropsychiatry Clin Neurosci (2012) 24:331-9. doi:10.1176/appi.neuropsych.11080192

113. Hart CL, Marvin CB, Silver R, Smith EE. Is cognitive functioning impaired in methamphetamine users? A critical review. Neuropsychopharmacology (2012) 37:586-608. doi:10.1038/npp.2011.276

114. Cretzmeyer M, Sarrazin MV, Huber DL, Block RI, Hall JA. Treatment of methamphetamine abuse: research findings and clinical directions. J Subst Abuse Treat (2003) 24:267-77. doi:10.1016/S0740-5472(03)00028-X

115. Halkitis PN, Shrem MT. Psychological differences between binge and chronic methamphetamine using gay and bisexual men. Addict Behav (2006) 31:549-52. doi:10.1016/j.addbeh.2005.05.040

116. Semple SJ, Patterson TL, Grant I. A comparison of injection and non-injection methamphetamine-using HIV positive men who have 
sex with men. Drug Alcohol Depend (2004) 76:203-12. doi:10.1016/j. drugalcdep.2004.05.003

117. Semple SJ, Zians J, Grant I, Patterson TL. Impulsivity and methamphetamine use. J Subst Abuse Treat (2005) 29:85-93. doi:10.1016/j.jsat.2005.05.001

118. Hester R, Lee N, Pennay A, Nielsen S, Ferris J. The effects of modafinil treatment on neuropsychological and attentional bias performance during 7-day inpatient withdrawal from methamphetamine dependence. Exp Clin Psychopharmacol (2010) 18:489-97. doi:10.1037/a0021791

119. Elkashef A, Rawson RA, Smith E, Pearce V, Flammino F, Campbell J, et al. The NIDA methamphetamine clinical trials group: a strategy to increase clinical trials research capacity. Addiction (2007) 102(Suppl 1):107-13. doi:10.1111/j.1360-0443.2007.01779.x

120. Radfar SR, Rawson RA. Current research on methamphetamine: epidemiology, medical and psychiatric effects, treatment, and harm reduction efforts. Addict Health (2014) 6:146-54.

121. Chang L, Cloak C, Patterson K, Grob C, Miller EN, Ernst T. Enlarged striatum in abstinent methamphetamine abusers: a possible compensatory response. Biol Psychiatry (2005) 57:967-74. doi:10.1016/j.biopsych.2005.01.039

122. London ED, Berman SM, Voytek B, Simon SL, Mandelkern MA, Monterosso J, et al. Cerebral metabolic dysfunction and impaired vigilance in recently abstinent methamphetamine abusers. Biol Psychiatry (2005) 58:770-8. doi:10.1016/j.biopsych.2005.04.039

123. Johanson C-E, Frey KA, Lundahl LH, Keenan P, Lockhart N, Roll J, et al. Cognitive function and nigrostriatal markers in abstinent methamphetamine abusers. Psychopharmacology (2006) 185:327-38. doi:10.1007/ s00213-006-0330-6

124. Monterosso JR, Ainslie G, Xu J, Cordova X, Domier CP, London ED. Frontoparietal cortical activity of methamphetamine-dependent and comparison subjects performing a delay discounting task. Hum Brain Mapp (2007) 28:383-93. doi:10.1002/hbm.20281

125. Hoffman WF, Moore M, Templin R, McFarland B, Hitzemann RJ, Mitchell $\mathrm{SH}$. Neuropsychological function and delay discounting in methamphetamine-dependent individuals. Psychopharmacology (2006) 188:162-70. doi:10.1007/s00213-006-0494-0

126. Leland DS, Arce E, Miller DA, Paulus MP. Anterior cingulate cortex and benefit of predictive cueing on response inhibition in stimulant dependent individuals. Biol Psychiatry (2008) 63:184-90.

127. Salo R, Ursu S, Buonocore MH, Leamon MH, Carter C. Impaired prefrontal cortical function and disrupted adaptive cognitive control in methamphetamine abusers: a functional magnetic resonance imaging study. Biol Psychiatry (2009) 65:706-9. doi:10.1016/j.biopsych.2008.11.026

128. Nestor LJ, Ghahremani DG, Monterosso J, London ED. Prefrontal hypoactivation during cognitive control in early abstinent methamphetamine-dependent subjects. Psychiatry Res (2011) 194:287-95. doi:10.1016/j.pscychresns.2011.04.010

129. Payer DE, Lieberman MD, Monterosso JR, Xu J, Fong TW, London ED. Differences in cortical activity between methamphetamine-dependent and healthy individuals performing a facial affect matching task. Drug Alcohol Depend (2008) 93:93-102. doi:10.1016/j.drugalcdep.2007.09.009

130. Hoffman WF, Schwartz DL, Huckans MS, McFarland BH, Meiri G, Stevens AA, et al. Cortical activation during delay discounting in abstinent methamphetamine dependent individuals. Psychopharmacology (2008) 201:183-93. doi:10.1007/s00213-008-1261-1

131. Brewer JA, Worhunsky PD, Carroll KM, Rounsaville BJ, Potenza MN. Pretreatment brain activation during Stroop task is associated with outcomes in cocaine-dependent patients. Biol Psychiatry (2008) 64:998-1004. doi:10.1016/j.biopsych.2008.05.024

132. Kober H, DeVito EE, DeLeone CM, Carroll KM, Potenza MN. Cannabis abstinence during treatment and one-year follow-up: relationship to neural activity in men. Neuropsychopharmacology (2014) 39:2288-98. doi:10.1038/ npp. 2014.82

133. Lopez RB, Onyemekwu C, Hart CL, Ochsner KN, Kober H. Boundary conditions of methamphetamine craving. Exp Clin Psychopharmacol (2015) 23:436-44. doi:10.1037/pha0000049

134. DeVito EE, Worhunsky PD, Carroll KM, Rounsaville BJ, Kober H, Potenza MN. A preliminary study of the neural effects of behavioral therapy for substance use disorders. Drug Alcohol Depend (2012) 122:228-35. doi:10.1016/j. drugalcdep.2011.10.002

135. Everitt BJ, Robbins TW. Drug addiction: updating actions to habits to compulsions ten years on. Annu Rev Psychol (2016) 67:23-50. doi:10.1146/ annurev-psych-122414-033457

136. Liu X, Matochik JA, Cadet JL, London ED. Smaller volume of prefrontal lobe in polysubstance abusers: a magnetic resonance imaging study. Neuropsychopharmacology (1998) 18:243-52. doi:10.1016/ S0893-133X(97)00143-7

Conflict of Interest Statement: The authors declare that the research was conducted in the absence of any commercial or financial relationships that could be construed as a potential conflict of interest.

Copyright $\odot 2016$ Cadet and Bisagno. This is an open-access article distributed under the terms of the Creative Commons Attribution License (CC BY). The use, distribution or reproduction in other forums is permitted, provided the original author(s) or licensor are credited and that the original publication in this journal is cited, in accordance with accepted academic practice. No use, distribution or reproduction is permitted which does not comply with these terms. 